\title{
Different Responses in Mandarin Cultivars Uncover a Role of Cuticular Waxes in the Resistance to Citrus Canker
}

\author{
María A. Favaro, ${ }^{1,2,3}$ María C. Molina, ${ }^{1,2}$ Roxana A. Roeschlin,1,2 José Gadea, ${ }^{4}$ Norberto Gariglio, ${ }^{3}$ and \\ María R. Marano ${ }^{1,2, \dagger}$ \\ ${ }^{1}$ Instituto de Biología Molecular y Celular de Rosario (IBR)-Consejo Nacional de Investigaciones Científicas y Tecnológicas (CONICET), \\ Ocampo y Esmeralda S/N, S2000FHN Rosario, Argentina \\ 2 Área Virología, Facultad de Ciencias Bioquímicas y Farmacéuticas, Universidad Nacional de Rosario, Suipacha 590, S2002LRK \\ Rosario, Argentina \\ ${ }^{3}$ Instituto de Ciencias Agropecuarias del Litoral, Universidad Nacional del Litoral, CONICET, Facultad de Ciencias Agrarias, Kreder 2805, \\ 3080 HOF Esperanza, Santa Fe, Argentina \\ ${ }^{4}$ Instituto de Biología Molecular y Celular de Plantas (IBMCP), Universidad Politécnica de Valencia-CSIC, Ingeniero Fausto Elio, S/N, 46022 \\ Valencia, España \\ Accepted for publication 19 June 2020.
}

\begin{abstract}
'Okitsu' is a mandarin cultivar showing substantial resistance to $X$. citri subsp. citri $(X$. citri). We have previously shown that this cultivar has significantly lower canker incidence and severity than 'Clemenules', particularly during early stages of leaf development in the field. This differential response is only seen when the leaves are inoculated by spraying, suggesting that leaf surface contributes to resistance. In this work, we have studied structural and chemical properties of leaf surface barriers of both cultivars. Ultrastructural analysis showed a thicker cuticle covering epidermal surface and guard cells in young 'Okitsu' leaves than in 'Clemenules'. This thicker cuticle was associated with a smaller stomatal aperture and reduced cuticle permeability. These findings correlated with an accumulation of cuticular wax components, including
\end{abstract}

ABSTRACT primary alcohols, alkanes, and fatty acids. None of these differences were observed in mature leaves, where both cultivars are equally resistant to the bacterium. Remarkably, mechanical alteration of cuticular thickness of young 'Okitsu' leaves allows canker development. Furthermore, cuticular waxes extracted from young 'Okitsu' leaves have higher antibacterial activity against $X$. citri than 'Clemenules'. Taken together, these data suggest that a faster development of epicuticular waxes in 'Okitsu' leaves play a central role in its resistance to $X$. citri.

Keywords: bacteriology, canker disease resistance, cuticle, cuticular thickness, genetics and resistance, 'Okitsu' mandarin, stomatal defense, waxes, Xanthomonas
Plants have evolved multiple mechanisms to defend against pathogen invasion. The first line of defense is the plant surface composed by preformed structural barriers such as the cuticle, considered a specialized lipidic modification of the epidermal cell wall (Domínguez et al. 2011; Samuels et al. 2008; Yeats and Rose 2013). The cuticle covers the aerial parts of plants, which is dominated by the leaves forming the phyllosphere, and it serves as a key interface between plant and environment, protecting against invading pathogens and abiotic stresses (Aragón et al. 2017; Yeats and Rose 2013; Ziv et al. 2018). The plant cuticle is mainly composed of cutin, a lipid-derived polyester, and waxes, which are either embedded in the cutin matrix (intracuticular waxes) or deposited on its outer surface (epicuticular waxes) (Aragón et al.

†Corresponding author: M. R. Marano; marano@ibr-conicet.gov.ar

Current address of R. A. Roeschlin: Facultad de Ciencias Agropecuarias, Universidad Católica de Santa Fe, Ludueña 612, S3560DYR Reconquista, Santa Fe, Argentina.

First and second authors contributed equally to this work.

Funding: This work was mainly supported by the Agencia Nacional de Promoción Cientifica y Tecnologica (PICT-2016-1222) to M. R. Marano, (PICT-2015-0261) to M. A. Favaro and by a Programa de Cooperacion Bilateral CONICET-CSIC PCB II 2013 to M. R. Marano and J. Gadea. M. R. Marano, M. A. Favaro, and R. A. Roeschlin are Career Investigators of CONICET; M. A. Favaro, R. A. Roeschlin, and M. C. Molina were supported by postdoctoral and doctoral scholarships from CONICET.

The author(s) declare no conflict of interest.

(c) 2020 The American Phytopathological Society
2017; Domínguez et al. 2011; Samuels et al. 2008). The architecture and composition of the cuticle varies between plant species, organs and developmental stages. The molecular basis of cuticle biosynthesis, export and regulation has been extensively studied in the model plant Arabidopsis, as well as in crop plants, including tomato, maize, rice, citrus, and Brassica napus (Lee and Suh 2015; Liu et al. 2015; Samuels et al. 2008; Wang et al. 2014, 2016).

The cuticle is the first contact with bacteria when they land on the leaf surface. In order to cope with this defensive barrier, many foliar pathogenic bacteria have evolved the ability to adhere and develop biofilm on the host surface before gaining access into the intercellular spaces of the mesophyll tissue through stomata (Melotto et al. 2008; Rigano et al. 2007; Vojnov and Marano 2015). Plant genotype play a major role in determining the structure of the phyllosphere, interfering with the ability to develop biofilm, a key factor of bacterial pathogenicity (Bodenhausen et al. 2014; Favaro et al. 2014; Schlechter et al. 2019; Whipps et al. 2008). It has been demonstrated that thicker and less permeable cuticles might interfere with epiphytic bacterial colonization, inhibiting the wetting of the leaf surface and limiting solubilization and diffusion of nutrients from the leaf (Bodenhausen et al. 2014; Lindow and Brandl 2003; Schlechter et al. 2019). Moreover, stomatal density and structure could also play an important role as preformed physical barriers against bacterial infection (Gonçalves-Zuliani et al. 2016; Wang et al. 2011).

The second line of plant defense is triggered by the perception of conserved pathogen-associated molecular patterns by cell surface pattern-recognition receptors (PRRs) in the plasma membrane (Couto and Zipfel 2016). Activation of PRR-mediated response results in stomatal closure, limiting bacterial proliferation at early 
18-day-old 36-day-old

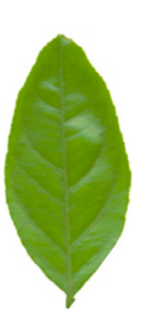

B

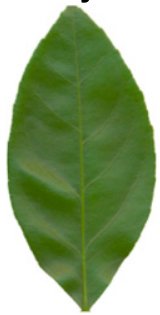

'Okitsu'

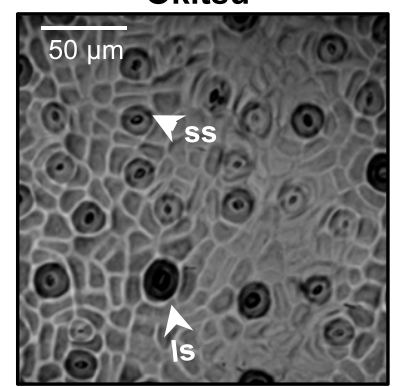

'Clemenules'

18-day-old 36-day-old

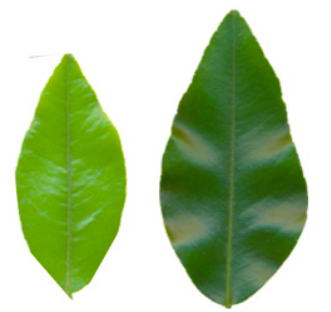

'Clemenules'

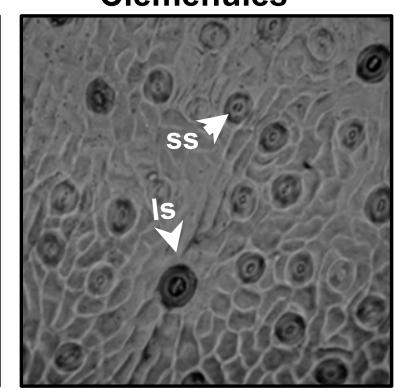

C
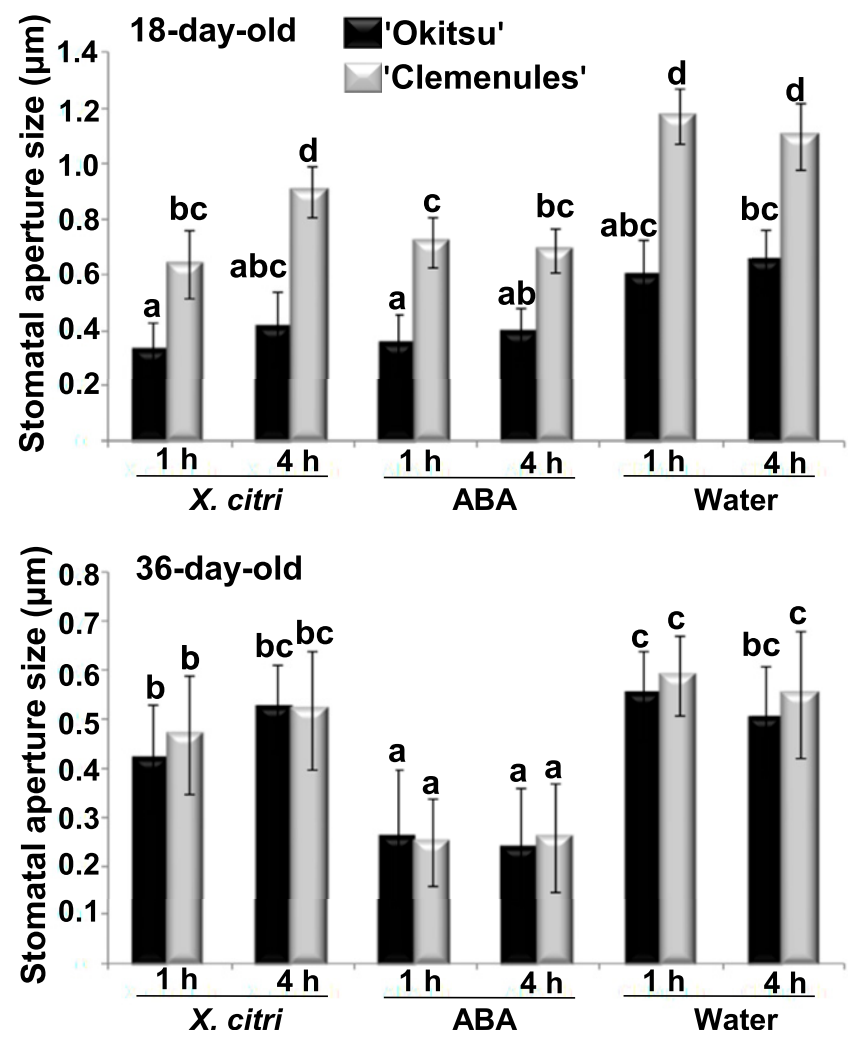

Fig. 1. Comparison of stomatal distribution and aperture size between 'Okitsu' and 'Clemenules' leaves. A, Phenological stages of young (18-day-old) and mature (36-day-old) 'Okitsu' and 'Clemenules' leaves. B, Dried-gel imprint of intact mandarin epidermis showing stomatal distribution in young leaves. 1s, large stomata; and ss, small stomata. C, Quantification of stomatal aperture at 1 and $4 \mathrm{~h}$ postinoculation in leaves exposed to Xanthomonas citri infection and abscisic acid (ABA) or water treatments by spraying. Values are expressed as the means \pm standard deviation from three independent experiments $(n=50$ stomata). Different letters above the bars indicate significant differences at $P<$ 0.05 (three-way analysis of variance, Tukey's test). stages of infection. However, pathogenic bacteria can reverse the stomatal-based defense and fully colonize the host plant (Chiesa et al. 2019; Melotto et al. 2017). A further level of induced defense is initiated by host recognition of effectors that are secreted into cells, resulting in the triggering of multiple responses that lead to the arrest of bacterial growth (Cesari 2018; Toruño et al. 2016).

Xanthomonas citri subsp. citri $(X$. citri) is the causal agent of Asiatic citrus canker, a disease that seriously affects most of the world's commercial citrus cultivars. Infected fruits have decreased commercial quality, compromising the acceptance by most markets (Ference et al. 2018). Evaluations in field and controlled conditions suggest that several types of Citrus and closely related genera, including C. ichangensis, C. junos, C. medica, C. mitis; C. unshiu, 'Dalan Dalan' (a cultivar similar to $C$. paradisi), Citrofortunella spp., Fortunella spp., and 'Lakeland' limequat (C. aurantifolia $\times$ F. japonica) are resistant to X. citri (Chen et al. 2012; De Carvalho et al. 2015; Deng et al. 2010; Favaro et al. 2014; Gochez and Canteros 2008; Gonçalves-Zuliani et al. 2016: Graham et al. 1992; Lee et al. 2009; Shiotani et al. 2009; Viloria et al. 2004; Wang et al. 2011). However, in some of these pathosystems quantitative resistance present in field is fully or partially broken down when invasive inoculation methods, such as pressure infiltration or pin prick inoculation, are used. This suggests that preformed defenses at the plant surface might be involved in the resistance to bacterial invasion (Favaro et al. 2014; Gonçalves-Zuliani et al. 2016; Graham et al. 1992; Wang et al. 2011).

The mechanisms underlying plant preformed defense and its relevance for limiting bacterial pathogen entry to the apoplast remain poorly understood. It has been reported that smaller stomatal density, size and aperture, and also higher epicuticular wax content contribute to the differential response to $X$. citri infection between the resistant kumquat genotype 'Meiwa' and the susceptible navel orange genotype 'Newhall' (Wang et al. 2011). In addition, a smaller stomatal aperture was associated with a lower susceptibility to $X$. citri in 'Pera' IAC orange, but no differences were observed in the stomatal density between this genotype and the more susceptible 'Washington navel' (Gonçalves-Zuliani et al. 2016).

Previously, we have shown that the resistance to $X$. citri in C. unshiu 'Okitsu' was associated with a faster phenological development of the leaf during the period of maximal susceptibility to $X$. citri infection, which might be coincident with a rapid cuticle development (Favaro et al. 2014). In addition, the resistance to $X$. citri was evident in bacterial spray-inoculated plants but not in those inoculated by infiltration, suggesting that the leaf surface contributes to quantitative resistance, limiting bacterial epiphytic fitness and biofilm formation.

In this work, we have studied the structural and chemical properties of leaf surface barriers of two mandarin cultivars to shed light on the differences that lead to resistance or development of citrus canker disease. Our findings highlight the multiple functions of the thicker 'Okitsu' cuticle in limiting bacterial establishment, including small stomatal aperture, low water permeability and a fast development of cuticular waxes. Furthermore, the amount of cuticular waxes in the early stage of leaf development is associated with antimicrobial activity against $X$. citri.

\section{MATERIALS AND METHODS}

Plant material and bacterial inoculation. One-year-old 'Clemenules' (C. clementina Hort. ex Tan.) and 'Okitsu' (C. unshiu Marc.) plants, grafted onto Poncirus trifoliata (L.) Raf. rootstocks were kept in a growth chamber, with a temperature range of 25 to $28^{\circ} \mathrm{C}$, high humidity ( $>95 \%$ ), a $14 \mathrm{~h}$ photoperiod, and a light intensity of 150 to $200 \mathrm{~m}^{-2-1}$. New shoots of approximately $1 \mathrm{~cm}$ size with at least five leaves were selected after pruning the plants. All the leaves of the same shoot were considered to be of the same ontological age. Experiments described in this work were done in young (18-day-old) and mature (36-day-old) leaves (Fig. 1A). 
These phenological development stages showed maximal and minimal differences between cultivars to canker disease (Favaro et al. 2014).

Bacterial suspensions of $X$. citri strain $\mathrm{A}^{\mathrm{E} 28}\left(10^{7} \mathrm{CFU} \mathrm{ml^{-1 } )}\right.$ were prepared in $10 \mathrm{mM} \mathrm{MgCl}_{2}$ and inoculated spraying mandarin leaves (Favaro et al. 2014). Inoculated plants were kept in a growth chamber.

Stomatal density and stomatal aperture analysis. Stomatal density, spatial distribution and aperture size were evaluated in abaxial epidermis imprints of the leaf, obtained using cyanoacrylate adhesive, according to Chiesa et al. (2019). Stomatal density was determined as the number of stomata per square millimeter. Spatial distribution of stomata was evaluated considering the predominant stomatal type and the relation between the number of large and small stomata.

To evaluate stomatal aperture, mandarin plants were exposed to light for at least $3 \mathrm{~h}$ at 150 to $200 \mathrm{~m}^{-2}-1,70 \%$ humidity, and temperatures ranging from 25 to $28^{\circ} \mathrm{C}$ before beginning the experiment. Leaves were inoculated with $X$. citri suspensions. As control of stomatal closure and opening, $20 \mu \mathrm{m}$ ABA (mixed isomers; Sigma-Aldrich, St. Louis, MO, U.S.A.) and water were used, respectively.

Imprints of abaxial epidermis (sample) were observed under a light microscope (BH2; Olympus Optical Ltd. Company, Shinjuku, Tokyo, Japan). For the different treatments and times, photographs were taken of at least 10 random zones per sample. Eighteen samples were obtained from six leaves collected from two different plants. Three independent experiments were conducted yielding similar results. The width of 50 random stomatal apertures was measured for each treatment and time point, using the software Image J v 1.41 (National Institutes of Health, Bethesda, MD, U.S.A.).

Cuticular permeability. For assessing the permeability of mandarin leaf surfaces to water-soluble molecules, toluidine blue staining was adapted from a previously described protocol (Bessire et al. 2007) with some modifications. Tissue samples (five pieces of $1 \mathrm{~cm}^{2}$ per leaf) were decolorized in $95 \%$ ethanol, equilibrated in $0.2 \mathrm{M} \mathrm{NaPO}_{4}(\mathrm{pH} \mathrm{9.0)}$ ) for $1 \mathrm{~h}$, and incubated in $0.05 \%$ (wt/vol) toluidine blue solution for up to $6 \mathrm{~h}$. Tissue samples treated with water and processed as described above were used as controls. Dye penetration to cells was examined with an Olympus BX50F4 microscope (Olympus Optical Ltd. Company). Toluidine blue is a polychromatic dye, therefore the color observed depends on the tissue staining (O'Brien et al. 1964). The samples were photographed in a Molecular Imager ChemiDoc TM XRS+ Imaging System (Bio-Rad, U.S.A.) and quantification of permeability was performed using a standard dye curve and the Quantity One software (Bio-Rad). Each experiment involved at least 15 samples per treatment, obtained from three different leaves, each one collected from different plants. Three independent experiments were conducted yielding similar results.

Transmission electron microscopy (TEM). The ultrastructure of the abaxial leaf cuticle was analyzed by TEM. Leaf sections (samples) from both mandarin cultivars were prepared and observed according to Roeschlin et al. (2017). Cuticle thickness was measured at three points of the epidermis using the Software Image J v 1.41 (National Institutes of Health). At least six different photographs were analyzed per leaf section. Samples from three different leaves, obtained from different plants were analyzed for each leaf age and genotype.

Total wax extraction. Cuticular wax from leaves surface was extracted as described by Beattie and Marcell (2002) with minor modification. A pool of young or mature leaves $\left(150 \mathrm{~cm}^{2}, \sim 20\right.$ to 15 leaves according to phenological development) randomly selected from three different 'Okitsu' and 'Clemenules' plants were fully submerged in $50 \mathrm{ml}$ of chloroform (Merck, Darmstadt, Germany). After stirring for $1 \mathrm{~min}$ at room temperature, the solvent was evaporated under a gentle stream of nitrogen. Total wax concentration was expressed in micrograms per square centimeter of leaf area. The obtained samples were processed according to Wang et al. (2014) either for gas chromatography-mass spectrometry (GC-MS) analysis or antibacterial activity assays. Control (blank) samples were prepared in the same way as other samples, except that no leaves were added. Three independent experiments were conducted yielding similar results.

Wax analysis by GC-MS. Wax composition of cuticular waxes of mandarin leaves was analyzed according to Wang et al. (2014), using capillary GC (Agilent 7890B, Agilent Technologies, Santa Clara, CA, U.S.A.) coupled with MS detector (5977A, Agilent Technologies) and a HP-5ms UI capillary column (30 m, $0.25 \mathrm{~mm}$ inner diameter, $0.25 \mu \mathrm{m}$ film thickness, Agilent Technologies). Helium was used as a carrier gas at a flow rate of

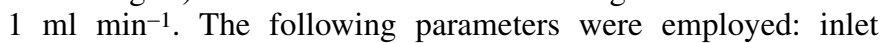
temperature $250^{\circ} \mathrm{C}$, MS transfer line temperature $280^{\circ} \mathrm{C}$, ion source temperature $230^{\circ} \mathrm{C}$, electron impact (EI) $70 \mathrm{eV}$, and $\mathrm{m} / \mathrm{z}$, range 50 to 750. Wax components were identified using a mass spectral database (NIST MS Library SW Kit, 2011b, Agilent Technologies). The relative percentage of each compound was determined by dividing the integrated area of the peak of the specific ion for the compound in question $(\times 100)$ by the summed value for the areas of all peaks (Chen et al. 2014). Three independent experiments were conducted yielding similar results.

RNA isolation and expression analysis of cuticleassociated genes. The transcriptional levels of seven genes related to wax biosynthetic pathways were analyzed by quantitative polymerase chain reaction (qPCR). Total RNA from mandarin leaves $(100 \mathrm{mg}$ ) was isolated according to the manufacturer's instructions (NucleoSpin RNA, Macherey-Nagel, Dueren, Germany). Reverse transcription was performed by M-MLV reverse transcription (Invitrogen, Carlsbad, CA, U.S.A.) with $1 \mu \mathrm{g}$ of DNase-treated total RNA and oligo-dT12-18 as primers. Synthesized cDNA was used for qPCR. Seven candidate genes potentially involved in mandarin cuticle formation were selected from the C. clementina genome database (https://phytozome.jgi.doe.gov/) based on the homology to corresponding Arabidopsis genes with known functions in leaf cuticular wax biosynthesis. The gene locus, function of gene product, primers sequences and PCR conditions are given in Table 1 . The reactions were carried out with real-time PCR master mix (Biodynamics SRL, BA, Argentina), and monitored in a Mastercycler ep realplex system (Eppendorf, Hamburg, Germany). Relative transcript abundance between samples was normalized against histone H4 (Shiotani et al. 2007) as an internal standard using the $\Delta \Delta C t$ method (Livak and Schmittgen 2001). 'Clemenules' leaves served as the reference sample. Each assay was performed with three different samples, involving three different leaves from three different plants. Three independent experiments were conducted yielding similar results.

Mechanical removal of 'Okitsu' cuticular waxes and canker development. Epicuticular waxes were removed from the abaxial surface of 'Okitsu' 18-day-old leaves by cotton swab and with gum arabic, according to Marcell and Beattie (2002) and Gniwotta et al. (2005), respectively. For gum arabic treatment, an aqueous solution of the adhesive was applied onto the entire abaxial surface of the leaves using a small paintbrush. After 1 to $2 \mathrm{~h}$, the gum arabic solution formed a dry and stable polymer film in which wax crystals were embedded and the film was extracted without damaging the leaves. Leaves subjected to both treatments and untreated 'Okitsu' and 'Clemenules' leaves were inoculated with $X$. citri suspensions $\left(10^{7} \mathrm{CFU} \mathrm{m} \mathrm{m}^{-1}\right)$ by spraying onto the abaxial epidermis of mandarin leaves, according to Favaro et al. (2014). Inoculated plants were kept for 30 days in a growth chamber. All plant inoculations involved a minimum of two shoots with at least five leaves from each plant and four plants for each mandarin cultivar. Disease progression was monitored phenotypically and through analysis of bacterial growth curves. Fifteen days postinoculation (dpi) samples were processed for TEM analysis 
(Roeschlin et al. 2017). For determination of bacterial population, three leaf disks of $1 \mathrm{~cm}^{2}$ were selected randomly from the inoculated leaves. The disks were immersed in $500 \mu \mathrm{l}$ of $10 \mathrm{mM}$ $\mathrm{MgCl}_{2}$ in Eppendorf microfuge tubes. Bacterial cells were collected by homogenization of tissue with a plastic pestle. The suspension was stirred at room temperature for $5 \mathrm{~min}$ and serial dilutions of this suspension were plated on $1.8 \%$ agar NYG medium (peptone extract at $5 \mathrm{~g} \mathrm{liter}^{-1}$, yeast extract at $3 \mathrm{~g} \mathrm{liter}^{-1}$, and glycerol at $20 \mathrm{~g}$ liter ${ }^{-1}$ ) supplemented with $100 \mathrm{~g} \mathrm{ml}^{-1}$ ampicillin, to estimate the total bacterial numbers. Leaf samples were taken during 1 week to determine bacterial population sizes on the leaves. At each time point, samples were determined from three separate experiments and each experiment was measured in triplicate. Three independent experiments were conducted yielding similar results.

Antibacterial activity assays of cuticular waxes. Microbicidal properties of cuticular waxes from mandarin leaves were tested in vitro against $X$. citri. A pool of young leaves $\left(150 \mathrm{~cm}^{2}, \sim 20\right.$ leaves) randomly selected from three different 'Okitsu' and 'Clemenules' plants were fully submerged in $50 \mathrm{ml}$ of chloroform (Merck, Darmstadt, Germany) and processed as described above. The extracted cuticular waxes were dissolved in $200 \mu \mathrm{l}$ of chloroform (Merck) and used in the screening of antibacterial activity on NYG agar plates. Spots of approximately $50 \mu \mathrm{l}$ of each wax extract (corresponding to the wax present in $37.5 \mathrm{~cm}^{2}$ of leaf) were deposited in triplicate onto $1.8 \%$ agar NYG supplemented with ampicillin at $100 \mathrm{~g} \mathrm{ml}^{-1}$. As control, spots of $50 \mu \mathrm{l}$ of chloroform were deposited onto agar plates. Ten microliters of $X$. citri suspensions $\left(10^{4} \mathrm{CFU} \mathrm{ml}{ }^{-1}\right.$ in $\left.10 \mathrm{mM} \mathrm{MgCl}_{2}\right)$ was inoculated over the dry wax extracts and control. The plates were incubated at $28^{\circ} \mathrm{C}$ for $72 \mathrm{~h}$ and the colonies grown on each spot were counted using the Software Image J v 1.41 (National Institutes of Health). Three independent experiments were conducted yielding similar results.

For determination of bactericidal activity in NYG liquid medium, the assay was adapted from the method described by Golus et al. (2016). Cuticular waxes from young leaves $\left(150 \mathrm{~cm}^{2}\right)$ were extracted and processed as described above. The extracted cuticular waxes were dissolved in $15 \mu \mathrm{l}$ of dimethylsulfoxide (DMSO, Merck), and $2 \mu \mathrm{l}$ of this extract was mixed with $200 \mu \mathrm{l}$ of $X$. citri suspension $\left(10^{6} \mathrm{CFU} \mathrm{ml}-1\right.$ in $10 \mathrm{mM} \mathrm{MgCl}_{2}$ ) and deposited in triplicate on 96-well Clear Flat Bottom Polystyrene TC-treated Microplates (Corning, U.S.A.). As control of bacterial growth, $2 \mu \mathrm{l}$ of DMSO was mixed with $200 \mu \mathrm{l}$ of $X$. citri suspension $\left(10^{6} \mathrm{CFU}\right.$ $\mathrm{ml}^{-1}$ in $10 \mathrm{mM} \mathrm{MgCl} 2$. The plate was incubated at $28^{\circ} \mathrm{C}$, and bacterial growth was assessed by microplate reader (Bio Tek Synergy 2 Multi-Detection, U.S.A.) at $600 \mathrm{~nm}$. Three independent experiments were conducted yielding similar results.

Statistical analyses. Data were analyzed according to Student's $t$ test $(P<0.05)$ through InfoStat Software v2017 (Di Rienzo et al. 2017), excepting stomatal aperture and bacterial population data that were subjected to a three-way analysis of variance (ANOVA: cultivar, time, and treatment) and one-way ANOVA, respectively. In both cases, the means were analyzed using Tukey's test $(P<0.05)$.

\section{RESULTS}

The stomatal pore aperture is smaller in young 'Okitsu' leaves than in 'Clemenules'. In order to investigate the role of stomatal density and size in the resistance to $X$. citri, imprints of abaxial epidermis of 18-day-old leaves of both mandarin cultivars were analyzed (Fig. 1A). No apparent qualitative differences were observed in the disposition of guard cells in relation to the subsidiary cells, showing both cultivars the same stomatal complex (anomocytic type, Fig. 1B). Moreover, the relation between the number of large and small stomata was similar to that reported for other Citrus species (Graham et al. 1992). In addition, no differences were observed in the stomatal density, indicated by the number of stomata per square millimeter between 'Okitsu' and 'Clemenules' (943 \pm 64 and 1,004 \pm 41 , respectively, $P<0.05$, Student's $t$ test).

In order to investigate the role of stomatal response to $X$. citri in both mandarin cultivars during the different phenological leaf stages (young and mature leaves), bacterial promotion of stomatal closure was analyzed at 1 and $4 \mathrm{~h}$ postinoculation (hpi). ABA and water were used as control of stomatal closure and opening, respectively (Chiesa et al. 2019; Melotto et al. 2008). Interestingly, stomatal aperture was significantly smaller in 'Okitsu' than in

TABLE 1. Primers of mandarin cuticle-associated genes involved in wax biosynthesis used for qPCR analysis ${ }^{\mathrm{a}}$

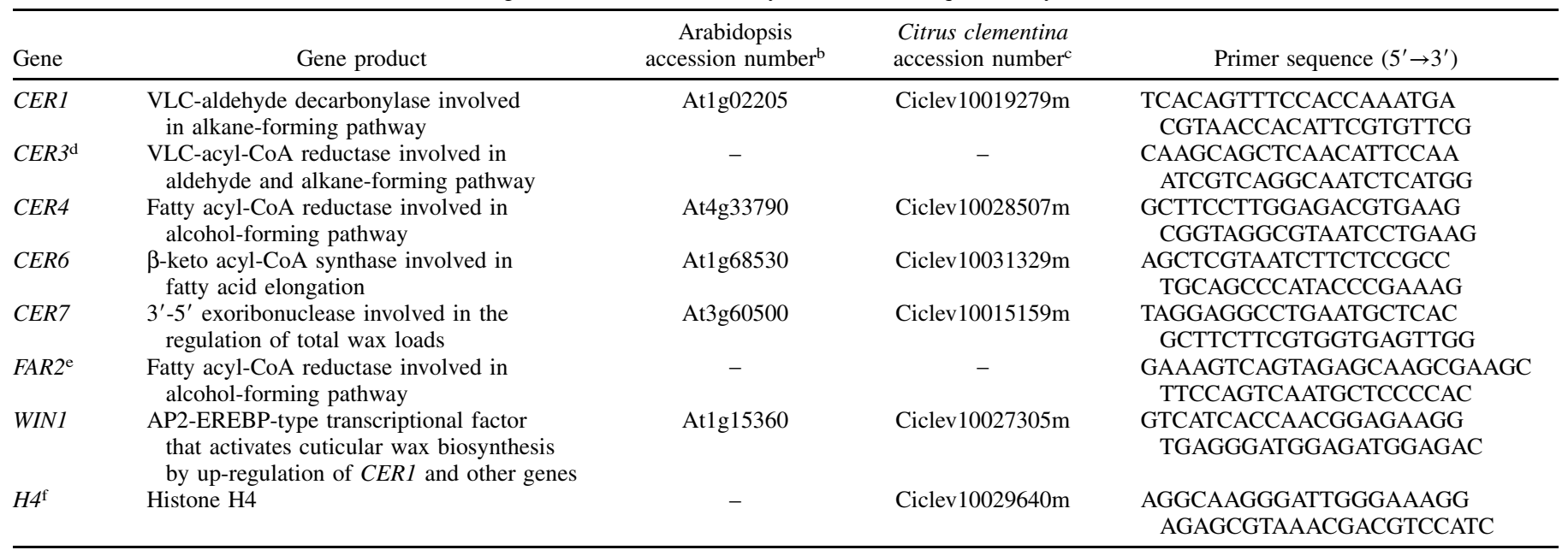

${ }^{a} C E R 1$, eceriferum 1; CER3, eceriferum 3; CER4, acyl-CoA reductase; CER6, $\beta$-ketoacyl-CoA synthase KCS6/eceriferum 6; CER7, eceriferum 7; FAR2, acyl$\mathrm{CoA}$ reductase; and WIN1, wax inducer 1 transcription factor. qPCRs were performed for 40 cycles according to the following conditions: denaturation at $95^{\circ} \mathrm{C}$ for $15 \mathrm{~s}$, annealing at $57^{\circ} \mathrm{C}$ for $30 \mathrm{~s}$, and extension at $72^{\circ} \mathrm{C}$ for $40 \mathrm{~s}$. After amplification, melting-curve analyses were performed to exclude artifactual amplifications.

b Arabidopsis genome database (http://www.arabidopsis.org).

c C. clementina genome database (http://www.phytozome.net).

${ }^{\mathrm{d}}$ Matas et al. (2010).

e Liu et al. (2015).

f Shiotani et al. (2007). 
'Clemenules' at 1 hpi in 18-day-old leaves either for bacterial inoculation or control treatments (Fig. 1C). Moreover, at 4 hpi, $X$. citri reversed stomatal closure in 'Clemenules' whereas 'Okitsu' stomatas remained closed. Nevertheless, in mature leaves (36-dayold), stomatal aperture and response to bacterial infection or treatments were similar in both mandarin cultivars (Fig. 1C).

These findings suggest that a smaller stomatal aperture in young 'Okitsu' leaves may be one component of the surface barriers that contributes to the resistance to $X$. citri infection.

'Okitsu' show reduced cuticle permeability in young leaves. We previously demonstrate that young 'Okitsu' leaves interfere with plant-associated bacterial biofilms required for $X$. citri pathogenicity and canker development (Favaro et al. 2014). We hypothesized that the inhibition of bacterial adhesion and biofilm formation may be associated with a reduced cuticle permeability limiting solubilization and diffusion of nutrients from the leaf in this mandarin cultivar. To test this, permeability of the cuticle of 18-day-old leaves was assessed with toluidine blue and monitored over $6 \mathrm{~h}$. After $30 \mathrm{~min}$, only 'Clemenules' epidermal tissue showed accumulation of the dye (blue staining) within the guard cells and cell wall junctions (Fig. 2). Six hours after incubation with the staining solution, 'Clemenules' showed a deep penetration of the dye to subepidermal leaf tissue, indicated by the characteristic reddish staining of parenquimatic tissue. The percentage of cuticular permeability to the dye was 1.5 -fold higher in 'Clemenules' than in 'Okitsu' $(58.0 \pm 4 \%$ and $37.2 \pm 3 \%$, respectively, $P<0.05$, Student's $t$ test), suggesting a negative relation between permeability and resistance to $X$. citri. As expected, the percentage of dye penetration was similar in 36-day-old leaves of both mandarin cultivars $(31.8 \pm 4 \%$ and $35.6 \pm 2 \%$, respectively).

A thick and deeper extending cuticle covers epidermal surface and guard cells in young 'Okitsu' leaves. To gain insight into the relationship between cuticular permeability and thickness in the resistance to $X$. citri the ultrastructure of the cuticle in both mandarin cultivars was analyzed by TEM during the main phenological stages of the leaf that show clear differences in susceptibility to $X$. citri infection (Fig. 3). Eighteen-day-old 'Okitsu' leaves showed a thicker cuticle than 'Clemenules', which covers the pavement epidermal cells and formed stomatal edges in the guard cells (Fig. 3A). In addition, in some areas 'Okitsu' cuticle penetrates deeply in the epidermal cell wall junctions, leading to the cuticularization of the anticlinal cell wall, generating a flat continuous layer on the epidermis. Conversely, in 'Clemenules', a thin cuticle covers the surface of epidermal cells, leaving depressions between epidermal cells junctions, designing a sinuous topography in the epidermal layer (Fig. 3A). In contrast, no differences in cuticle thickness were observed in mature (36-dayold) leaves between both mandarin cultivars (Fig. 3B).

Taken together, our data suggest that a faster cuticle development takes place in young 'Okitsu' leaves, where it may play a substantial role as a preformed physical barrier against $X$. citri infection.

The thick cuticle in young 'Okitsu' leaves is associated with an early accumulation of cuticular wax components. The plant cuticle waxes are predominantly composed of a mixture of aliphatic very long chain fatty acid (VLCFA) and their derivatives, as well as cyclic compounds including triterpenoid and sterols (Samuels

\section{'Okitsu'}
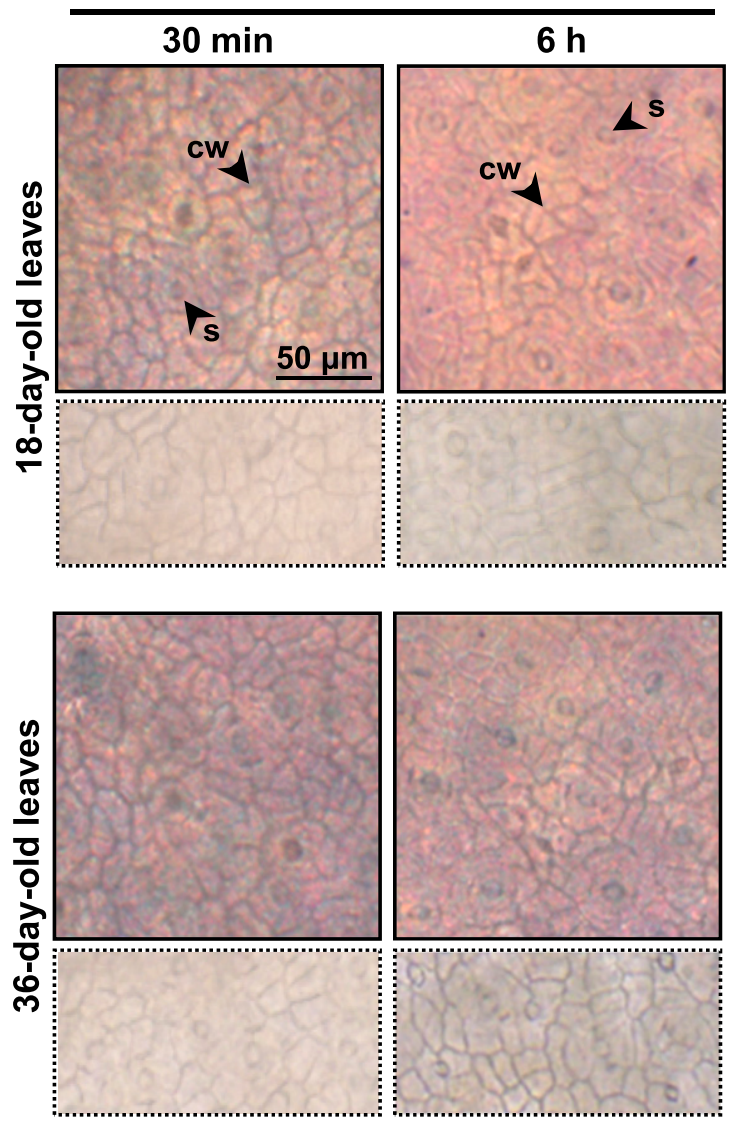

\section{'Clemenules'}
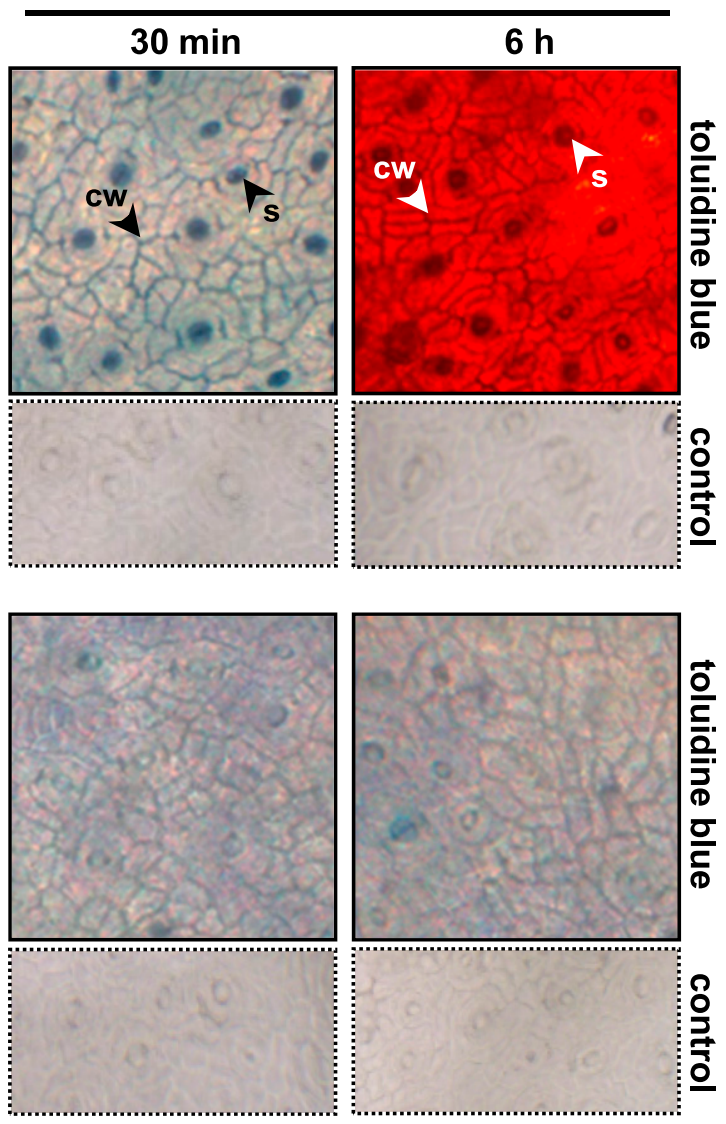

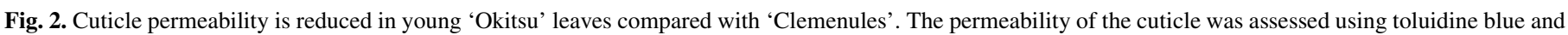

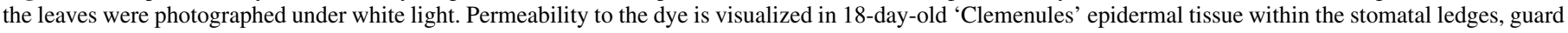

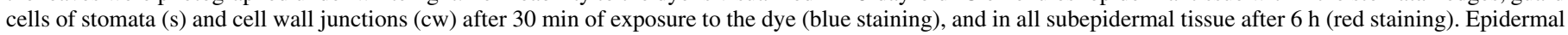

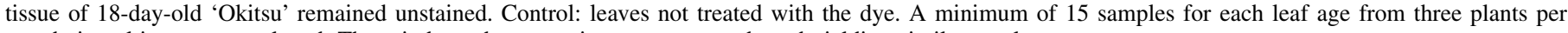
mandarin cultivar were analyzed. Three independent experiments were conducted yielding similar results. 
et al. 2008). To evaluate if there is a relationship between wax amount and resistance to $X$. citri, we studied the levels of total waxes in young and mature leaves from 'Okitsu' and 'Clemenules'.

In accordance with the increase of cuticular thickness, 18-dayold 'Okitsu' leaves showed significantly higher accumulation of total waxes per leaf unit area $\left(13.9 \pm 0.9 \mu \mathrm{g} \mathrm{cm}^{-2}\right)$ than 'Clemenules' $\left(3.7 \pm 0.3 \mu \mathrm{g} \mathrm{cm}^{-2}\right)$. Nevertheless, the chemical analysis of wax components of these leaf samples through GC-MS shows that wax profile shares high similarities between 'Okitsu' and 'Clemenules' (Table 2). The most abundant cuticular wax fraction in both mandarin cultivars was the primary alcohols, representing $96.6 \%$ in 'Okitsu' and $95.7 \%$ in 'Clemenules' of the GC-MS-detected compounds. They were accompanied by minor amounts of nalkanes (2.4 and 3.2\% for 'Okitsu' and 'Clemenules', respectively) and fatty acids $(0.5$ and $0.6 \%$ for 'Okitsu' and 'Clemenules', respectively). In the primary alcohol fraction, even-number homologs prevailed, such as hexacosanol $\left(\mathrm{C}_{26}\right)$, tetracosanol $\left(\mathrm{C}_{24}\right)$ and octacosanol $\left(\mathrm{C}_{28}\right)$. The second group was integrated by alkanes between $\mathrm{C}_{22}$ and $\mathrm{C}_{31}$, such as docosano $\left(\mathrm{C}_{22}\right)$, tricosano $\left(\mathrm{C}_{23}\right)$ untriacontano $\left(\mathrm{C}_{31}\right)$, heptacosano $\left(\mathrm{C}_{27}\right)$, nonacosano $\left(\mathrm{C}_{29}\right)$ and pentacosano $\left(\mathrm{C}_{25}\right)$. Tetracosanoic $\left(\mathrm{C}_{24}\right)$, octadecanoic $\left(\mathrm{C}_{18}\right)$, hexadecanoic $\left(\mathrm{C}_{16}\right)$, and docosanoic $\left(\mathrm{C}_{22}\right)$ fatty acids established the third group in abundance of aliphatic lipids. Considering the differences between the total amounts of waxes per leaf unit area among the mandarin cultivars, the quantity of all these compounds was higher in 'Okitsu' than in 'Clemenules'. On the other hand, in 36-dayold leaves, the wax levels increased notably in 'Clemenules' (16.4 \pm $\left.0.5 \mu \mathrm{g} \mathrm{cm}^{-2}\right)$, reaching similar accumulation than in 'Okitsu' (18.2 \pm $0.2 \mu \mathrm{g} \mathrm{cm}^{-2}$ ). In this developmental stage, the predominant compounds were similar to those found in 18-day-old cuticle leaves and new compounds corresponding to aliphatic lipids of longer carbon chains were present in trace amounts in both cultivars, suggesting changes in the wax composition during leaf development.

The higher accumulation of waxes in 18-day-old 'Okitsu' leaf in comparison with 'Clemenules', suggests differences in expression of wax biosynthesis pathways between both mandarin cultivars. To further investigate this, the expression of candidate genes related to cuticular wax-biosynthesis was analyzed (Table 1; Fig. 4). Remarkably, the relative expression of CER6, a $\beta$-ketoacyl- CoA synthase (KCS), key in catalyzing the first step in VLCFAs formation was 4.6-fold higher in young 'Okitsu' leaves than in 'Clemenules'. Furthermore, the expression of CER1 and CER3, which are involved in VLC alkane synthesis, was increased in the resistant cultivar compared with 'Clemenules' (induced by 5 -fold and 4.5-fold, respectively). In the same way, the level of expression of WIN1, a transcription factor that regulates the expression of $C E R 1$, and CER7, a regulatory transcription factor of CER3 (Hooker et al. 2007), was also elevated in the resistant cultivar (induced by 2.6 -fold and 1.8-fold, respectively). Interestingly, the expression levels of VLC alcohol-forming genes, such as CER4 and $F A R 2$ were higher in young 'Clemenules' leaves than in 'Okitsu'.

Taken together, these data show that resistance to $X$. citri correlates with a higher wax deposition, in accordance with the thicker cuticle shown in TEM analysis rather than differences in chemical cuticular composition.

Mechanical alteration of 'Okitsu' cuticle thickness allows $X$. citri colonization and canker development. To examine the hypothesis that the inhibition of bacterial survival on young 'Okitsu' leaf surface might be due to a higher wax accumulation, we analyzed the effect of reducing abaxial cuticle thickness on disease development.
A
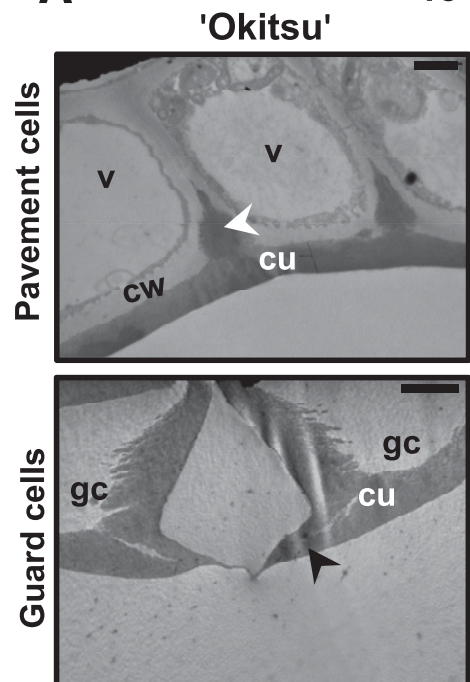

18-day-old

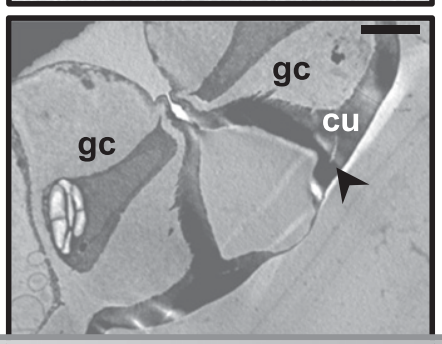

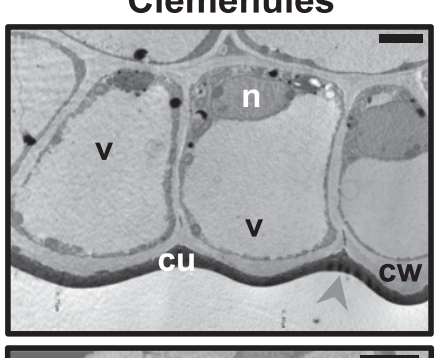

B
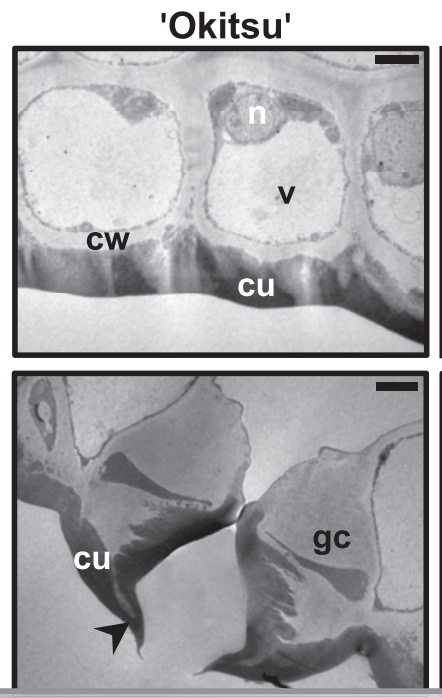

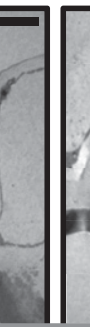

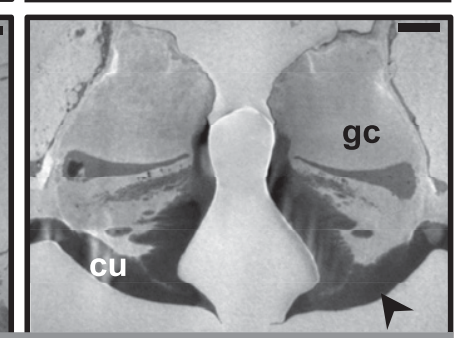

Cuticle thickness over pavement cells $(\mu \mathrm{m})$

\begin{tabular}{|c|c|c|}
\hline $1.24 \pm 0.20$ & $*$ & $0.78 \pm 0.10$ \\
\hline \multicolumn{3}{|c|}{ Cuticle thickness } \\
\hline $2.14 \pm 0.15$ & $*$ & $1.34 \pm 0.12$ \\
\hline
\end{tabular}

n.s.

$1.92 \pm 0.16$
$1.82 \pm 0.11$

\section{'Clemenules'}

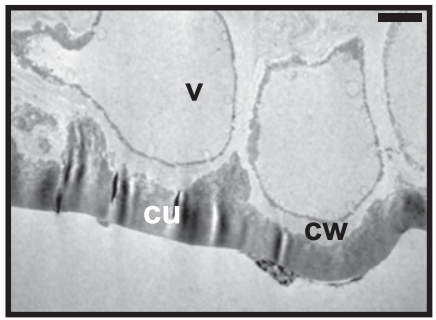

(n)

(1)

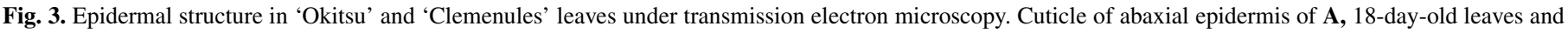

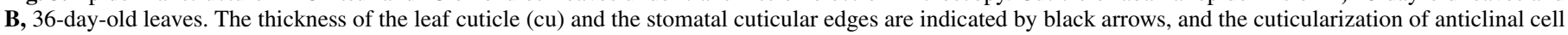

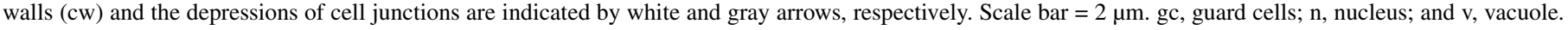

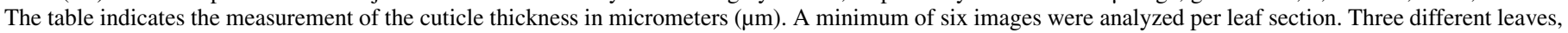

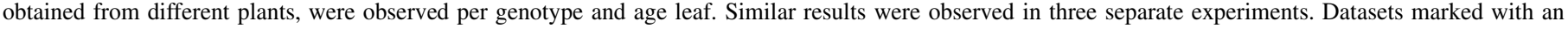
asterisk are significantly different as assessed by Student's $t$ test $(P<0.05)$. n.s. indicates not significant. 
Epicuticular waxes from the leaf surface were selectively removed without damage to the epidermal cells using either cotton swabs or gum arabic (Gniwotta et al. 2005; Marcell and Beattie 2002).

Ultrastructural analysis showed that gum arabic and cotton swab treatments reduced cuticular thickness in epidermal pavement and guard cells from 18-day-old 'Okitsu' leaves. Cuticular thicknesses were $0.29 \pm 0.09 \mu \mathrm{m}$ and $0.18 \pm 0.08 \mu \mathrm{m}$, for gum arabic and cotton swab treatments, respectively, compared with $1.24 \mu \mathrm{m}$ for untreated leaves (Fig. 5A). Untreated 18-day-old 'Okitsu' and 'Clemenules' leaves were used as controls. Both treated and untreated leaves were inoculated by spraying with $X$. citri. The integrity of the epidermal layer and mesophyll tissue in untreated 'Okitsu' leaves remained unaltered after bacterial inoculation (Fig. 5B). The population size of $X$. citri began to decline 3 dpi and no canker symptoms were observed after 20 days, as expected from previous work (Favaro et al. 2014) (Fig. 5C). Notably, at 15 dpi, surface-treated 'Okitsu' leaves, whose epicuticular waxes were removed, showed the presence of bacteria invading the intercellular space of a hypertrophied mesophyll tissue. Moreover, these samples showed similar ultrastructural changes by bacterial colonization to 18-day-old 'Clemenules' leaves (Fig. 5B). Similar bacterial growth was observed between the surface-treated 'Okitsu' and untreated 'Clemenules' leaves. In these tissue samples, X. citri population gradually increased more than two orders of magnitude over the monitoring period that was correlated with the canker symptoms developed at 20 dpi (Fig. 5C).

These results confirm that 'Okitsu' cuticle interferes with $X$. citri fitness affecting early events required for bacterial infection and consequently mesophyll colonization.
Cuticular waxes inhibit $X$. citri growth. In order to determine if cuticular waxes from young 'Okitsu' leaves also act as an inhibitor of pathogen survival, we performed in vitro antibacterial activity assays. In an attempt to reproduce the

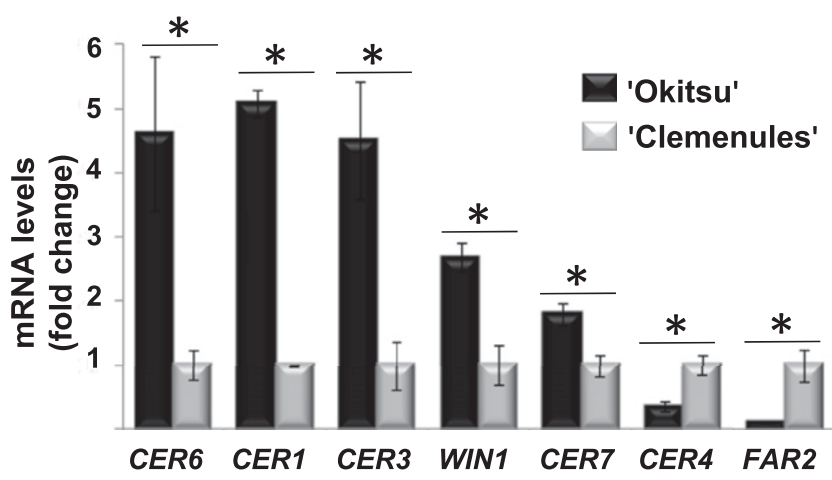

Fig. 4. Expression analysis of genes involved in cuticular wax biosynthesis. Quantitative polymerase chain reaction analysis of $\beta$-ketoacyl-CoA synthase KCS6/eceriferum 6 (CERO), eceriferum 1 (CER1), eceriferum 3 (CER3), wax inducer 1 transcription factor (WIN1), eceriferum 7 (CER7), fatty acyl-CoA reductase $(C E R 4)$, and fatty acyl-CoA reductase (FAR2) mRNAs measured in 18-day-old leaves. The relative gene expression $(\Delta \Delta \mathrm{Ct})$ fold change was performed considering 'Clemenules' leaves as reference samples and a histone $H 4$ transcript as an endogenous control. Values are expressed as means \pm standard deviation from three independent assays. Datasets marked with an asterisk are significantly different as assessed by Student's $t$ test $(P<0.05)$.

TABLE 2. Cuticular waxes and their composition in 'Clemenules' and 'Okitsu' leaves ${ }^{\mathrm{a}}$

\begin{tabular}{|c|c|c|c|c|}
\hline \multirow[b]{4}{*}{ Wax coverage $\left(\mu \mathrm{g} \mathrm{cm}^{-2}\right)$} & \multicolumn{4}{|c|}{ Wax composition $(\%)$} \\
\hline & \multicolumn{2}{|c|}{ 18-day-old leaves } & \multicolumn{2}{|c|}{ 36-day-old leaves } \\
\hline & 'Okitsu' & 'Clemenules' & 'Okitsu' & 'Clemenules' \\
\hline & 13.90 & $3.70 *$ & 18.20 & 16.40 n.s. \\
\hline \multicolumn{5}{|l|}{ Primary alcohols } \\
\hline Hexacosanol $\left(\mathrm{C}_{26}\right)$ & $58.55 \pm 0.055$ & $49.38 \pm 0.031$ & $49.34 \pm 0.729$ & $40.10 \pm 0.817$ \\
\hline Tetracosanol $\left(\mathrm{C}_{24}\right)$ & $23.94 \pm 0.054$ & $32.50 \pm 0.021$ & $21.65 \pm 0.094$ & $27.45 \pm 0.128$ \\
\hline Octacosanol $\left(\mathrm{C}_{28}\right)$ & $9.36 \pm 0.045$ & $8.51 \pm 0.046$ & $10.86 \pm 0.024$ & $9.72 \pm 0.047$ \\
\hline Pentacosanol $\left(\mathrm{C}_{25}\right)$ & $1.94 \pm 0.007$ & $2.18 \pm 0.034$ & $2.28 \pm 0.076$ & $2.62 \pm 0.073$ \\
\hline Heptacosanol $\left(\mathrm{C}_{27}\right)$ & $1.26 \pm 0.010$ & $1.16 \pm 0.050$ & $1.69 \pm 0.056$ & $1.83 \pm 0.078$ \\
\hline Docosanol $\left(\mathrm{C}_{22}\right)$ & $0.75 \pm 0.000$ & $1.40 \pm 0.520$ & $1.01 \pm 0.087$ & $1.79 \pm 0.178$ \\
\hline Triacontanol $\left(\mathrm{C}_{30}\right)$ & $0.60 \pm 0.038$ & $0.18 \pm 0.042$ & $3.09 \pm 0.059$ & $1.36 \pm 0.066$ \\
\hline Tricosanol $\left(\mathrm{C}_{23}\right)$ & $0.11 \pm 0.029$ & $0.24 \pm 0.129$ & $0.17 \pm 0.022$ & $0.36 \pm 0.057$ \\
\hline Nonacosanol $\left(\mathrm{C}_{29}\right)$ & $0.06 \pm 0.008$ & $0.04 \pm 0.066$ & $0.30 \pm 0.036$ & $0.17 \pm 0.033$ \\
\hline Dotriacontanol $\left(\mathrm{C}_{32}\right)$ & $0.04 \pm 0.005$ & $0.13 \pm 0.007$ & $3.01 \pm 0.179$ & $1.87 \pm 0.131$ \\
\hline Untriacontanol $\left(\mathrm{C}_{31}\right)$ & $0.01 \pm 0.000$ & $0.02 \pm 0.047$ & $0.19 \pm 0.024$ & $0.09 \pm 0.035$ \\
\hline Tritriacontanol $\left(\mathrm{C}_{33}\right)$ & - & - & $0.07 \pm 0.011$ & $0.04 \pm 0.008$ \\
\hline Tetracontanol $\left(\mathrm{C}_{34}\right)$ & - & - & $0.04 \pm 0.036$ & $0.06 \pm 0.031$ \\
\hline Hexatriacontanol $\left(\mathrm{C}_{36}\right)$ & - & - & $0.01 \pm 0.005$ & - \\
\hline \multicolumn{5}{|l|}{ Alkanes } \\
\hline Untriacontano $\left(\mathrm{C}_{31}\right)$ & $0.54 \pm 0.008$ & $1.03 \pm 0.066$ & $2.27 \pm 0.016$ & $4.86 \pm 0.038$ \\
\hline Pentacosano $\left(\mathrm{C}_{25}\right)$ & $0.52 \pm 0.000$ & $0.52 \pm 0.256$ & - & $0.02 \pm 0.000$ \\
\hline Heptacosano $\left(\mathrm{C}_{27}\right)$ & $0.35 \pm 0.021$ & $0.57 \pm 0.232$ & $0.23 \pm 0.007$ & $0.44 \pm 0.023$ \\
\hline Docosano $\left(\mathrm{C}_{22}\right)$ & $0.35 \pm 0.144$ & $0.46 \pm 0.399$ & - & - \\
\hline Nonacosano $\left(\mathrm{C}_{29}\right)$ & $0.32 \pm 0.014$ & $0.18 \pm 0.114$ & $0.69 \pm 0.034$ & $0.59 \pm 0.037$ \\
\hline Tricosano $\left(\mathrm{C}_{23}\right)$ & $0.30 \pm 0.003$ & $0.11 \pm 0.010$ & $0.12 \pm 0.000$ & $1.69 \pm 0.000$ \\
\hline Octacosano $\left(\mathrm{C}_{28}\right)$ & - & - & $0.05 \pm 0.007$ & $0.08 \pm 0.003$ \\
\hline Dotriacontano $\left(\mathrm{C}_{32}\right)$ & - & - & $0.10 \pm 0.011$ & $0.60 \pm 0.018$ \\
\hline Tetratriacontano $\left(\mathrm{C}_{34}\right)$ & - & $0.20 \pm 0.025$ & $0.16 \pm 0.015$ & $1.95 \pm 0.051$ \\
\hline Tetracosano $\left(\mathrm{C}_{24}\right)$ & - & $0.26 \pm 0.111$ & $0.01 \pm 0.000$ & $0.01 \pm 0.000$ \\
\hline \multicolumn{5}{|l|}{ Fatty acids } \\
\hline Tetracosanoic acid $\left(\mathrm{C}_{24}\right)$ & $0.24 \pm 0.016$ & $0.36 \pm 0.005$ & $0.53 \pm 0.055$ & $0.50 \pm 0.058$ \\
\hline Octadecanoic acid $\left(\mathrm{C}_{18}\right)$ & $0.10 \pm 0.061$ & $0.13 \pm 0.000$ & $0.68 \pm 0.123$ & $1.68 \pm 0.123$ \\
\hline Hexadecanoic acid $\left(\mathrm{C}_{16}\right)$ & $0.06 \pm 0.018$ & $0.13 \pm 0.000$ & $0.43 \pm 0.062$ & $1.07 \pm 0.048$ \\
\hline Docosanoic acid $\left(\mathrm{C}_{22}\right)$ & $0.06 \pm 0.005$ & - & $0.09 \pm 0.010$ & $0.05 \pm 0.006$ \\
\hline Hexacosanoic acid $\left(\mathrm{C}_{26}\right)$ & $0.11 \pm 0.000$ & $0.05 \pm 0.002$ & $0.26 \pm 0.015$ & $0.20 \pm 0.017$ \\
\hline
\end{tabular}

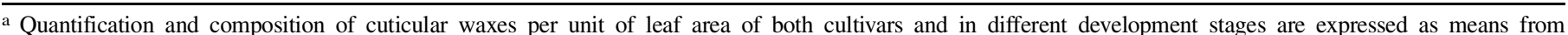
three independent experiments. The dataset marked with an asterisk is significantly different as assessed by Student's $t$ test $(P<0.05)$. n.s. indicates not significant. 


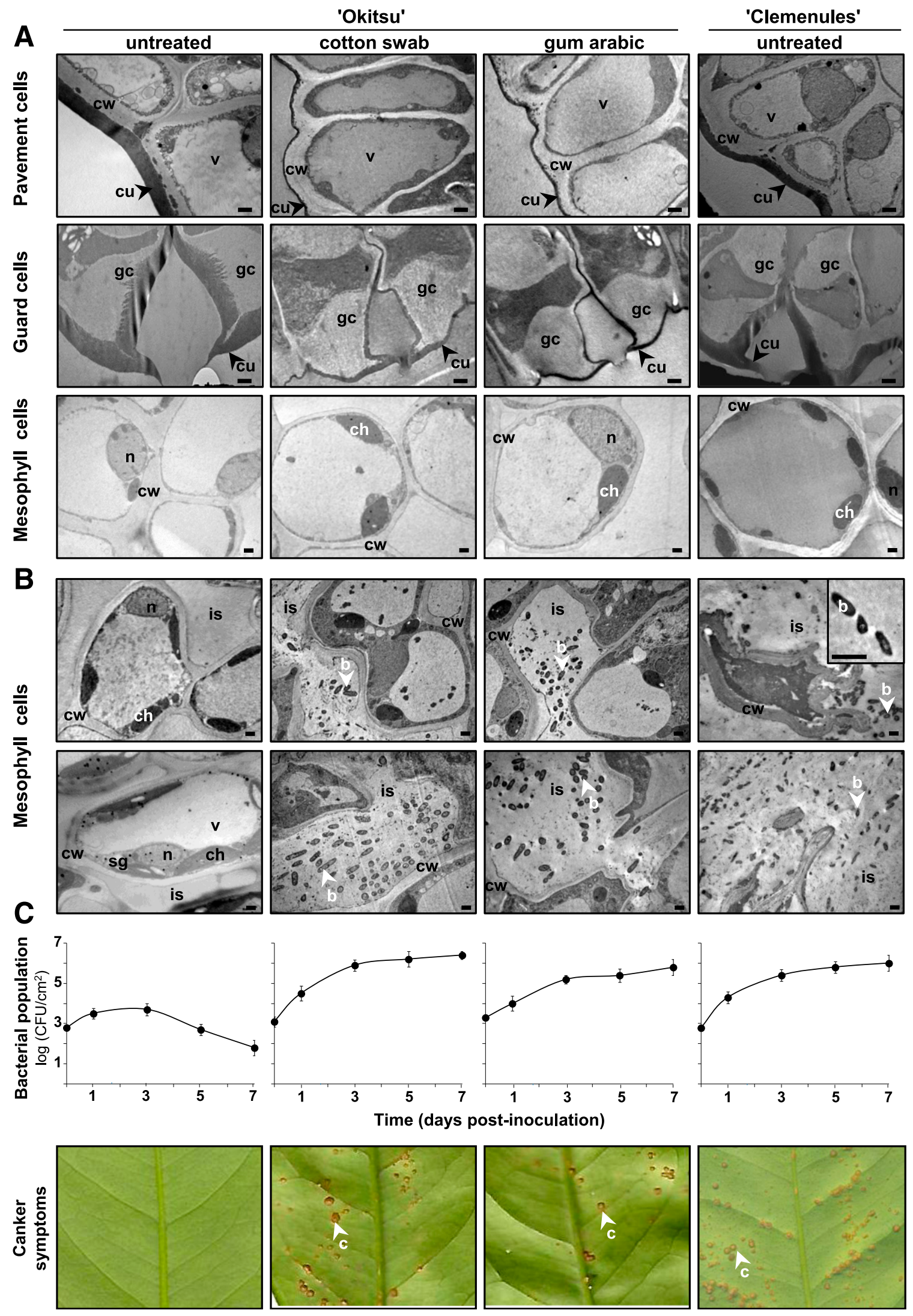

Fig. 5. Ultrastructural and phenotypic features of young 'Okitsu' leaves inoculated with Xanthomonas citri after removal of epicuticular wax. A, Overview of uninfected leaf tissue showing cuticle (cu) structure of pavement cells, guard cells (gc), and mesophyll tissue before and after mechanical removal of 'Okitsu' epicuticular waxes. Differences in cuticle thickness between leaves treated with cotton swab or gum arabic and untreated leaf (black arrow). Scale bar $=1 \mu \mathrm{m}$. B, Ultramorphological changes of $X$. citri-infected tissues 15 days postinoculation (dpi). Scale bar $=1 \mu \mathrm{m}$. b, bacteria; cw, cell wall; ch, chloroplast; $\mathrm{n}$, nucleus; is, intercellular space; sg, starch granule; and v, vacuole. C, In vivo growth of X. citri on treated mandarin leaves, whose epicuticular waxes were extracted, and untreated mandarin leaves. Values are expressed as means \pm standard deviation of triplicate measurements from three independent experiments. Bacterial populations in untreated 'Okitsu' leaves significantly differed from those found in 'Clemenules' and treated 'Okitsu' leaves from 3 to 7 dpi (one-way analysis of variance, Tukey's test, $P<$ 0.05). Symptom development induced by $X$. citri strain on lower surfaces of treated and untreated mandarin leaves 20 dpi. c, canker lesions. 
conditions in planta, $X$. citri was exposed to the cuticular waxes on solid medium. Cuticular waxes extracted from both 18-day-old young 'Okitsu' and 'Clemenules' leaves have a potent inhibitory effect on the growth of $X$. citri compared with the control (Fig. 6A). Notwithstanding, 'Okitsu' waxes have an antibacterial activity $50 \%$ higher than 'Clemenules', according to the level of cuticular waxes per leaf unit area (Fig. 6A). In order to follow the waxes effect on the bacterial growth over a $12 \mathrm{~h}$ time course, the cells were propagated in liquid medium supplemented with 'Okitsu' or 'Clemenules' cuticular waxes. This study confirmed that the higher amount of cuticular waxes per square centimeter of leaf area in 'Okitsu' compared with 'Clemenules' results in a greater antibacterial activity in the resistant cultivar (Fig. 6B). These results indicate that the increase of wax accumulation play a role in the resistance against $X$. citri, contributing not only as preformed defenses but also as an antimicrobial agent.

\section{DISCUSSION}

The plant leaf surface, or the phyllosphere, is one of the most important natural habitats for microorganisms. It has been demonstrated that epiphytic bacterial populations are directly influenced by certain environmental conditions of the phyllosphere such as fluctuating temperature, radiation, relative humidity, presence of free water, and the availability of plant-leached metabolites at the leaf surface, so that only adapted bacteria can survive (Aragón et al. 2017; Schlechter et al. 2019; Schreiber et al. 2005; Whipps et al. 2008). In previous studies, we showed that in young 'Okitsu' leaves surface defense barrier impedes epiphytic growth and biofilm formation of $X$. citri, conferring resistance to canker disease (Favaro et al. 2014). In this work, we investigated the physical and chemical characteristics of this defense barrier.

Changes in stomata aperture size are function of both guard and epidermal cell turgor, regulated by signaling components in guard cells in response to environmental conditions, including abiotic and biotic stress (Melotto et al. 2017). Our results indicate that a thicker cuticle is correlated with a smaller stomatal aperture and less permeable stomatal cuticular edges. Arabidopsis mutants that are unable to synthesize cutin have diminished cuticular projections surrounding the stomatal pore resulting in increased susceptibility to pathogens ( $\mathrm{Li}$ et al. 2007). Considering the range of stomatal aperture in young 'Okitsu' leaves $(0.3$ to $0.6 \mu \mathrm{M})$ and the $X$. citri size (1.5 to $2.0 \times 0.5$ to $0.75 \mu \mathrm{m}$ ) (Goto 1992), we could hypothesize that the stomatal cuticular edges enhance stomatal defense by reducing bacterial entry into the mesophyllic tissue. The absence of both bacterial proliferation and hypertrophy in the mesophyll tissue after bacterial inoculation of 'Okitsu' young leaves support this hypothesis.

We demonstrated that 'Okitsu' cuticle in young leaf is almost twofold thicker compared with 'Clemenules'. No differences in cuticle thickness between cultivars were observed in mature (36day-old) leaves. This result indicates that 'Okitsu' cuticle develops rapidly during the leaf expansion process, which is the period of optimal susceptibility to X. citri infection. A thicker 'Okitsu' cuticle was related with the fortification of epidermal anticlinal cell wall, which generates a smooth surface, whereas the leaf cuticle has a sinuous or rough surface in 'Clemenules'. It has been demonstrated that these cavities formed in epidermal cell wall junctions are protected sites where phytopathogenic bacteria survive (Lindow and Brandl 2003; Schlechter et al. 2019; Whipps et al. 2008). Furthermore, we found a negative relationship between the cuticular thickness and water permeability on 'Okitsu' leaf, which may be associated with a low availability of water and nutrients on leaf surface, preventing also the epiphytic growth of $X$. citri. It has been extensively demonstrated that changes in cuticle permeability influence plant-bacterial interactions (Aragón et al. 2017; Tang et al. 2007; Xiao et al. 2004; Yeats and Rose 2013; Ziv et al. 2018). Moreover, a number of epiphytic (pathogenic and nonpathogenic) bacteria have been shown to increase cuticular permeability, enhancing solubilization and diffusion of nutrient from the leaf to improve epiphytic fitness on the leaf surface (Lindow and Brandl 2003; Schreiber et al. 2005; Vacher et al. 2016; Whipps et al. 2008).

The cuticular thickness of 'Okitsu' and its consequence over leaf permeability could be explained considering a greater quantity of total cuticular waxes. In young 'Okitsu' leaves, the higher expression of genes involved in the first step of VLCFA formation, coupled with the up regulation of genes involved in VLC alkane production, resulted in a higher accumulation of wax constituents, may indicate that the wax biosynthetic pathways are induced earlier in this resistant cultivar compared with 'Clemenules' in the same phenological stage. Although primary alcohols dominated the wax mixture in leaves of both mandarin cultivars, the absolute amounts of these compounds (referred as $\mu \mathrm{g} \mathrm{cm}^{-2}$ of the leaf) differ between them. We could speculate that the higher expression levels of VLC alcohol-forming genes, such as CER4 and FAR2 in young 'Clemenules' leaves might mean an enhanced synthesis, to reach similar levels to 'Okitsu' in
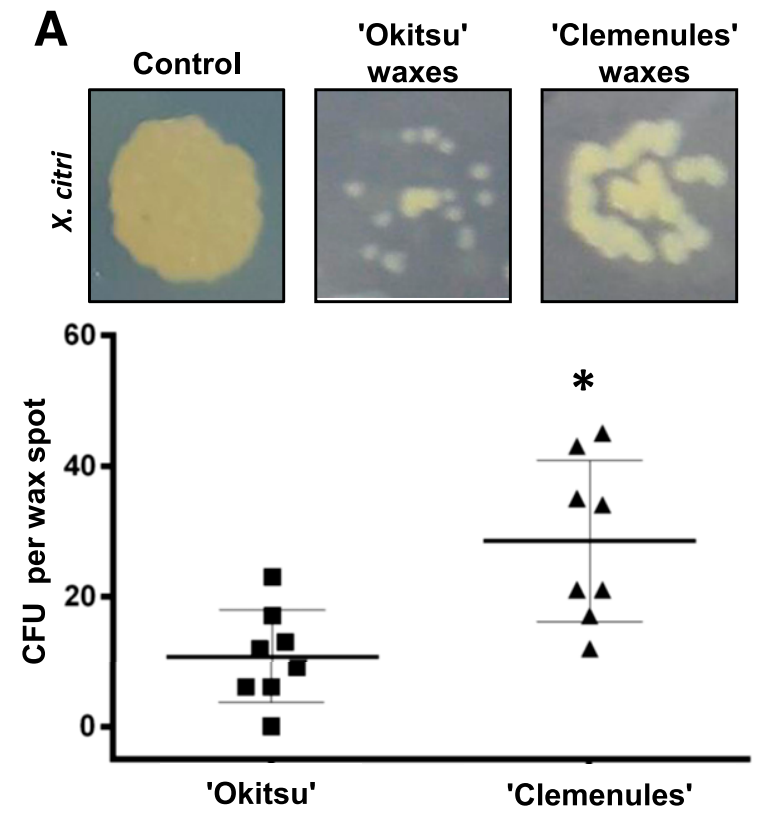

B

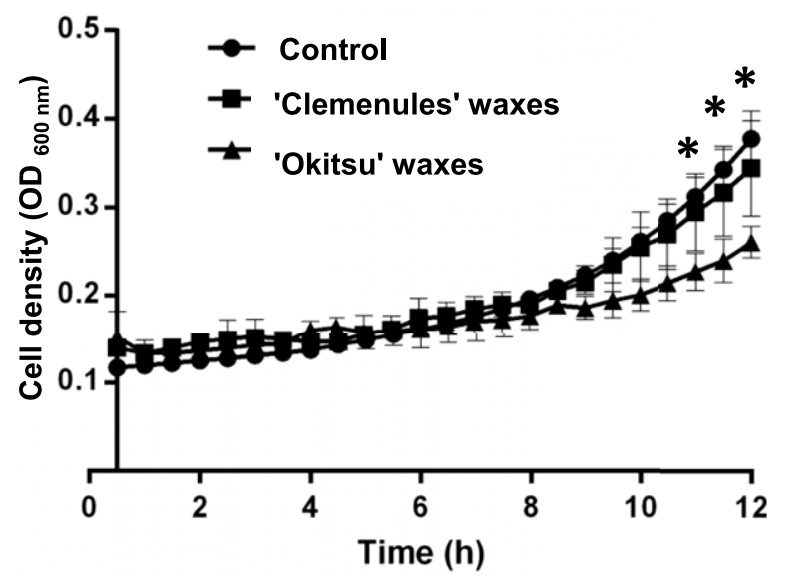

Fig. 6. Antimicrobial activity of cuticular wax extracts isolated from young 'Okitsu' and 'Clemenules' leaves against Xanthomonas citri. A, Growth of X. citri over cuticular wax and control spots in NYG medium (peptone extract at $5 \mathrm{~g} \mathrm{liter}^{-1}$, yeast extract at $3 \mathrm{~g} \mathrm{liter}^{-1}$, and glycerol at $20 \mathrm{~g} \mathrm{liter}^{-1}$ ) agar plate. The graph shows the number of bacterial colonies per mandarin cuticular wax spot. B, X. citri growth in NYG broth supplemented with cuticular wax extract. Values are expressed as means \pm standard deviation of three independent experiments. Datasets marked with an asterisk are significantly different as assessed by Student's $t$ test $(P<0.05)$. 
mature leaves. Riederer and Schneider (1990) also found a higher quantity of primary alcohols in C. aurantium as leaves age increased. The increase of cuticular wax production during leaf development has been also reported in other plant species (Lee and Suh 2015; Yeats and Rose 2013; Zhu et al. 2018).

It has been proposed that waxy broad-leaved plants support lower populations of culturable bacteria in the phyllosphere due to avoidance of water stagnation on the plant surface (Marcell and Beattie 2002; Whipps et al. 2008). Thus, the abundance of epicuticular waxes has been associated to a self-cleaning mechanism known as the lotus effect, which repels water avoiding pathogen establishment (Yeats and Rose 2013). Hydrophobicity of the epicuticular waxes depends on the nature of the chemical groups exposed on the surface (Marcell and Beattie 2002). Although there are no significant differences in cuticular wax compositions between 'Okitsu' and 'Clemenules', the larger amount of cuticular waxes in young 'Okitsu' leaves could be associated with a greater hydrophobicity compared with 'Clemenules', and consequently, with a greater water-repellent surface, which interferes with the proliferation of $X$. citri in the epiphytic phase. Glossy maize mutants ( $g l l, g l 3$, and $g l 5 / g l 20)$, which produce less epicuticular waxes and have a less hydrophobic surface than wild-type, support greater epiphytic growth of the pathogenic bacteria Clavibacter michiganensis, presumably due to the increased leaching of nutrients from mesophyll (Marcell and Beattie 2002). According to our results, the mechanical removal of epicuticular waxes of the abaxial surface of young 'Okitsu' leaves make it susceptible to X. citri infection, indicating that waxes are involved in the resistance mechanism. In accordance with our results, a high association between epicuticular wax content and resistance to $X$. citri was shown in Fortunella 'Meiwa' (Wang et al. 2011).

Over recent years, significant progress has been made to understand the biological role of cuticular waxes in the susceptibility or resistance to fungal infection (Aragón et al. 2017; Batista dos Santos et al. 2019; Hansjakob et al. 2010). However, there is no data about the activity of the Citrus leaf cuticular waxes against plant bacterial pathogens. Here, we show that cuticular waxes of both mandarin cultivars have antibacterial activity in vitro against $X$. citri. Nevertheless, cuticular waxes from young 'Okitsu' leaves have a greater inhibitor effect than 'Clemenules' at the same developmental stage, which is correlated with its higher amount of waxes. The most abundant wax components in both cultivars are primary alcohols, whose mix is known as policosanol. Further research is necessary to understand the importance of these compounds as antibacterial agents.

In conclusion, we provide evidence for the 'Okitsu' resistance to $X$. citri infection by physiological, biochemical, and ultrastructural analysis of its cuticle. The presence of a higher amount of cuticular waxes, particularly epicuticular ones, in the beginning of 'Okitsu' leaf development would lead to less susceptibility to $X$. citri infection in this genotype. Plant cuticle reinforcement in young leaves could then be used as a functional trait to manage foliar bacterial diseases.

\section{ACKNOWLEDGMENTS}

We thank M. Hourcade for her invaluable technical assistance in the GC-MS and J. Maxwell Dow and Lucila García for critical review of the manuscript.

\section{LITERATURE CITED}

Aragón, W., Reina-Pinto, J. J., and Serrano, M. 2017. The intimate talk between plants and microorganisms at the leaf surface. J. Exp. Bot. 68: 5339-5350.

Batista dos Santos, I. B., da Silva Lopes, M., Peres Bini, A., Prohmann Tschoeke, B. A., Wruck Verssani, B. A., Fernandes Figueredo, E., Regiani Cataldi, T., Rodrigues Marques, J. P., Duque Silva, L., Labate, C. A., and Quecine, M. C. 2019. The Eucalyptus cuticular waxes contribute in preformed defense against Austropuccinia psidii. Front. Plant Sci. 9:1978.

Beattie, G. A., and Marcell, L. M. 2002. Effect of alterations in cuticular wax biosynthesis on the physicochemical properties and topography of maize leaf surfaces. Plant Cell Environ. 25:1-16.

Bessire, M., Chassot, C., Jacquat, A.-C., Humphry, M., Borel, S., MacDonald-Comber Petétot, J., Métraux, J.-P., and Nawrath, C. 2007. A permeable cuticle in Arabidopsis leads to a strong resistance to Botrytis cinerea. EMBO J. 26:2158-2168.

Bodenhausen, N., Bortfeld-Miller, M., Ackermann, M., and Vorholt, J. A. 2014. A synthetic community approach reveals plant genotypes affecting the phyllosphere microbiota. PLoS Genet. 10:e1004283.

Cesari, S. 2018. Multiple strategies for pathogen perception by plant immune receptors. New Phytol. 219:17-24.

Chen, P.-S., Wang, L.-Y., Chen, Y.-J., Tzeng, K.-C., Chang, S.-C., Chung, K.-R., and Lee, M.-H. 2012. Understanding cellular defence in kumquat and calamondin to citrus canker caused by Xanthomonas citri subsp. citri. Physiol. Mol. Plant Pathol. 79:1-12.

Chen, S. J., Li, Y. C., Bi, Y., Yin, Y., Ge, Y. H., and Wang, Y. 2014. Solvent effects on the ultrastructure and chemical composition of cuticular wax and its potential bioactive role against Alternaria alternata in Pingguoli Pear. J. Integr. Agric. 13:1137-1145.

Chiesa, M. A., Roeschlin, R. A., Favaro, M. A., Uviedo, F., Campos Beneyto, L., D’Andrea, R., Gadea, J., and Marano, M. R. 2019. Plant responses underlying nonhost resistance of Citrus limon against Xanthomonas campestris pv. campestris. Mol. Plant Pathol. 20:254-269.

Couto, D., and Zipfel, C. 2016. Regulation of pattern recognition receptor signalling in plants. Nat. Rev. Immunol. 16:537-552.

De Carvalho, S. A., De Carvalho Nunes, W. M., Belasque Jr, J., Machado, M. A., Croce-Filho, J., Bock, C. H., and Abdo, Z. 2015. Comparison of resistance to Asiatic citrus canker among different genotypes of Citrus in a long-term canker-resistance field screening experiment in Brazil. Plant Dis. 99:207-218.

Deng, Z. N., Xu, L., Li, D. Z., Long, G. Y., Liu, L. P., Fang, F., and Shu, G. P. 2010. Screening citrus genotypes for resistance to canker disease (Xanthomonas axonopodis pv. citri). Plant Breed. 129:341-345.

Di Rienzo, J. A., Casanoves, F., Balzarini, M. G., González, L., Tablada, M., and Robledo, C. W. 2017. InfoStat version 2017. Grupo InfoStat, FCA, Universidad Nacional de Córdoba, Argentina. http://www.infostat.com.ar

Domínguez, E., Heredia-Guerrero, J. A., and Heredia, A. 2011. The biophysical design of plant cuticles: an overview. New Phytol. 189: 938-949.

Favaro, M. A., Micheloud, N. G., Roeschlin, R. A., Chiesa, M. A., Castagnaro, A. P., Vojnov, A. A., Gmitter, F. G., Jr., Gadea, J., Rista, L. M., Gariglio, N. F., and Marano, M. R. 2014. Surface barriers of mandarin 'Okitsu' leaves make a major contribution to canker disease resistance. Phytopathology 104:970-976.

Ference, C. M., Gochez, A. M., Behlau, F., Wang, N., Graham, J. H., and Jones, J. B. 2018. Recent advances in the understanding of Xanthomonas citri ssp. citri pathogenesis and citrus canker disease management. Mol. Plant Pathol. 19:1302-1318.

Gniwotta, F., Vogg, G., Gartmann, V., Carver, T. L. W., Riederer, M., and Jetter, R. 2005. What do microbes encounter at the plant surface? Chemical composition of pea leaf cuticular waxes. Plant Physiol. 139: 519-530.

Gochez, A. M., and Canteros, B. I. 2008. Resistance to citrus canker caused by Xanthomonas citri pv. citri in an accession of Citrus sp. similar to grapefruit. Plant Dis. 92:652.

Golus, J., Sawicki, R., Widelski, J., and Ginalska, G. 2016. The agar microdilution method, a new method for antimicrobial susceptibility testing for essential oils and plant extracts. J. Appl. Microbiol. 121:1291-1299.

Gonçalves-Zuliani, A. M. O., Cardoso, K. A. K., Belasque, J., Jr., Zanutto, C. A., Hashiguti, H. T., Bock, C. H., Nakamura, C. V., and Nunes, W. M. C. 2016. Reaction of detached leaves from different varieties of sweet orange to inoculation with Xanthomonas citri subsp. citri. Summa Phytopathol. 42: $125-133$

Goto, M. 1992. Citrus canker. Pages 250-269 in: Plant Diseases of International Importance, Vol. III, Diseases of Fruit Crops. J. Kumer, H. S. Chaube, U. S. Singh, and A. N. Mukhopadhyay, eds. Prentice Hall, Upper Saddle River, NJ.

Graham, J. H., Gottwald, T. R., Riley, T. D., and Achor, D. S. 1992. Penetration through leaf stomata and growth of strains of Xanthomonas campestris in citrus cultivars varying in susceptibility to bacterial diseases. Phytopathology 82:1319-1325.

Hansjakob, A., Bischof, S., Bringmann, G., Riederer, M., and Hildebrandt, U. 2010. Very-long-chain aldehydes promote in vitro prepenetration processes of Blumeria graminis in a dose- and chain length-dependent manner. New Phytol. 188:1039-1054. 
Hooker, T. S., Lam, P., Zheng, H., and Kunst, L. 2007. A core subunit of the RNA-processing/degrading exosome specifically influences cuticular wax biosynthesis in Arabidopsis. Plant Cell 19:904-913.

Lee, I. J., Kim, K. W., Hyun, J. W., Lee, Y. H., and Park, E. W. 2009. Comparative ultrastructure of nonwounded Mexican Lime and Yuzu leaves infected with the citrus canker bacterium Xanthomonas citri pv. citri. Microsc. Res. Tech. 72:507-516.

Lee, S. B., and Suh, M. C. 2015. Advances in the understanding of cuticular waxes in Arabidopsis thaliana and crop species. Plant Cell Rep. 34: 557-572.

Li, Y., Beisson, F., Koo, A. J. K., Molina, I., Pollard, M., and Ohlrogge, J. 2007. Identification of acyltransferases required for cutin biosynthesis and production of cutin with suberin-like monomers. Proc. Natl. Acad. Sci. USA 104:18339-18344.

Lindow, S. E., and Brandl, M. T. 2003. Microbiology of the phyllosphere. Appl. Environ. Microbiol. 69:1875-1883.

Liu, D. C., Yang, L., Zheng, Q., Wang, Y. C., Wang, M. L., Zhuang, X., Wu, Q., Liu, C. F., Liu, S. B., and Liu, Y. 2015. Analysis of cuticular wax constituents and genes that contribute to the formation of 'Ganqi 3', a spontaneous bud mutant from the wild-type 'Newhall' navel orange. Plant Mol. Biol. 88:573-590.

Livak, K. J., and Schmittgen, T. D. 2001. Analysis of relative gene expression data using real-time quantitative PCR and the $2^{-\Delta \Delta} \mathrm{T}$ method. Methods 25: 402-408.

Marcell, L. M., and Beattie, G. A. 2002. Effect of leaf surface waxes on leaf colonization by Pantoea agglomerans and Clavibacter michiganensis. Mol. Plant-Microbe Interact. 15:1236-1244.

Matas, A. J., Agustí, J., Tadeo, F. R., Talón, M., and Rose, J. K. C. 2010. Tissue-specific transcriptome profiling of the citrus fruit epidermis and subepidermis using laser capture microdissection. J. Exp. Bot. 61: 3321-3330.

Melotto, M., Underwood, W., and He, S. Y. 2008. Role of stomata in plant innate immunity and foliar bacterial diseases. Annu. Rev. Phytopathol. 46: 101-122.

Melotto, M., Zhang, L., Oblessuc, P. R., and He, S. Y. 2017. Stomatal defense a decade later. Plant Physiol. 174:561-571.

O'Brien, T., Feder, N., and McCully, M. E. 1964. Polychromatic staining of plant cell walls by toluidine blue O. Protoplasma 59:368-373.

Riederer, M., and Schneider, G. 1990. The effect of the environment on the permeability and composition of Citrus leaf cuticles. Planta 180:154-165.

Rigano, L. A., Siciliano, F., Enrique, R., Sendin, L., Filippone, P., Torres, P. S., Questa, J., Dow, J. M., Castagnaro, A. P., Vojnov, A. A., and Marano, M. R. 2007. Biofilm formation, epiphytic fitness, and canker development in Xanthomonas axonopodis pv. citri. Mol. Plant-Microbe Interact. 20:1222-1230.

Roeschlin, R. A., Favaro, M. A., Chiesa, M. A., Alemano, S., Vojnov, A. A., Castagnaro, A. P., Filippone, M. P., Gmitter, F. G., Jr., Gadea, J., and Marano, M. R. 2017. Resistance to citrus canker induced by a variant of Xanthomonas citri ssp. citri is associated with a hypersensitive cell death response involving autophagy-associated vacuolar processes. Mol. Plant Pathol. 18:1267-1281.

Samuels, L., Kunst, L., and Jetter, R. 2008. Sealing plant surfaces: cuticular wax formation by epidermal cells. Annu. Rev. Plant Biol. 59:683-707.

Schlechter, R. O., Miebach, M., and Remus-Emsermann, M. N. P. 2019. Driving factors of epiphytic bacterial communities: A review. J. Adv. Res. 19:57-65.
Schreiber, L., Krimm, U., Knoll, D., Sayed, M., Auling, G., and Kroppenstedt, R. M. 2005. Plant-microbe interactions: Identification of epiphytic bacteria and their ability to alter leaf surface permeability. New Phytol. 166:589-594.

Shiotani, H., Fujikawa, T., Ishihara, H., Tsuyumu, S., and Ozaki, K. 2007. A pthA homolog from Xanthomonas axonopodis pv. citri responsible for hostspecific suppression of virulence. J. Bacteriol. 189:3271-3279.

Shiotani, H., Uematsu, H., Tsukamoto, T., Shimizu, Y., Ueda, K., Mizuno, A., and Sato, S. 2009. Survival and dispersal of Xanthomonas citri pv. citri from infected Satsuma mandarin fruit. Crop Prot. 28:19-23.

Tang, D., Simonich, M. T., and Innes, R. W. 2007. Mutations in LACS2, a long-chain acyl-coenzyme A synthetase, enhance susceptibility to avirulent Pseudomonas syringae but confer resistance to Botrytis cinerea in Arabidopsis. Plant Physiol. 144:1093-1103.

Toruño, T. Y., Stergiopoulos, I., and Coaker, G. 2016. Plant-pathogen effectors: Cellular probes interfering with plant defenses in spatial and temporal manners. Annu. Rev. Phytopathol. 54:419-441.

Vacher, C., Hampe, A., Porté, A. J., Sauer, U., Compant, S., and Morris, C. E. 2016. The phyllosphere: Microbial jungle at the plant-climate interface. Annu. Rev. Ecol. Evol. Syst. 47:1-24.

Viloria, Z., Drouillard, D. L., Graham, J. H., and Grosser, J. W. 2004. Screening triploid hybrids of 'Lakeland' limequat for resistance to citrus canker. Plant Dis. 88:1056-1060.

Vojnov, A. A., and Marano, M. R. 2015. Biofilm formation and virulence in bacterial plant pathogens. Pages 21-34 in: Virulence Mechanisms of PlantPathogenic Bacteria. N. Wang, J. B. Jones, G. W. Sundin, F. F. White, S. A. Hogenhout, C. Roper, L. de La Fuente, and J. H. Ham, eds. American Phytopathological Society, St. Paul, MN.

Wang, J., Hao, H., Liu, R., Ma, Q., Xu, J., Chen, F., Cheng, Y., and Deng, X. 2014. Comparative analysis of surface wax in mature fruits between Satsuma mandarin (Citrus unshiu) and 'Newhall' navel orange (Citrus sinensis) from the perspective of crystal morphology, chemical composition and key gene expression. Food Chem. 153:177-185.

Wang, J., Sun, L., Xie, L., He, Y., Luo, T., Sheng, L., Luo, Y., Zeng, Y., Xu, J., Deng, X., and Cheng, Y. 2016. Regulation of cuticle formation during fruit development and ripening in 'Newhall' navel orange (Citrus sinensis Osbeck) revealed by transcriptomic and metabolomic profiling. Plant Sci. 243:131-144.

Wang, Y., Fua, X. Z., Liua, J. H., and Hong, N. 2011. Differential structure and physiological response to canker challenge between 'Meiwa' kumquat and 'Newhall' navel orange with contrasting resistance. Sci. Hortic. (Amsterdam) 128:115-123.

Whipps, J. M., Hand, P., Pink, D., and Bending, G. D. 2008. Phyllosphere microbiology with special reference to diversity and plant genotype. J. Appl. Microbiol. 105:1744-1755.

Xiao, F., Goodwin, S. M., Xiao, Y., Sun, Z., Baker, D., Tang, X., Jenks, M. A., and Zhou, J. M. 2004. Arabidopsis CYP86A2 represses Pseudomonas syringae type III genes and is required for cuticle development. EMBO J. 23:2903-2913.

Yeats, T. H., and Rose, J. K. C. 2013. The formation and function of plant cuticles. Plant Physiol. 163:5-20.

Zhu, X., Zhang, Y., Du, Z., Chen, X., Zhou, X., Kong, X., Sun, W., Chen, Z., Chen, C., and Chen, M. 2018. Tender leaf and fully-expanded leaf exhibited distinct cuticle structure and wax lipid composition in Camellia sinensis cv. Fuyun 6. Sci. Rep. 8:14944.

Ziv, C., Zhao, Z., Gao, Y. G., and Xia, Y. 2018. Multifunctional roles of plant cuticle during plant-pathogen interactions. Front. Plant Sci. 9:1088. 